\title{
Libertinaje en el siglo XVII ${ }^{i}$
}

\author{
Gabriel ALBIAC \\ Universidad Complutense de Madrid
}

\begin{abstract}
RESUMEN
En el presente artículo, se traza la genealogía polémica del término y el concepto de "libertinismo". Su sentido, tal como se forja en la primera Modernidad en la obra de Calvino, dentro del horizonte de la primera Reforma protestante, sería exclusivamente peyorativo y, sobre todo, obedecería a una estrategia eminentemente polémica: la de la construcción de una fantasmagoría frente a la cual dotar de solidez al cristianismo moderno.
\end{abstract}

PALABRAS CLAVE: Calvino, panteísmo, epicureísmo, subjetividad, moral

\begin{abstract}
This article tries to draw the polemical genealogy of the term and concept of "libertinism". Its sense, as it is forged in early Modernity, in the works of Calvin, and in the backgroud of the first Protestant Reformation, is merely contemptuous and, above all, it is due to a clearly critical strategy: the construction of a fictional enemy in confrontation with which it is possible to reinforce the basis of modern Christianism.
\end{abstract}

KEYWORDS: Calvin, pantheism, epicurism, subjectivity, morals

\section{Las metamorfosis del libertino}

«Entonces se levantaron unos en la sinagoga llamada de los libertinos, y de los de Cirene, de Alejandría, de Cilicia y de Asia, disputando con Esteban» ${ }^{1}$. El pasaje de los Hechos de los Apóstoles parece haber sido el soporte para los usos apologéticos de la polémica antilibertina, a partir de la reforma emprendida por Calvino en Ginebra. No obstante, a poco que se lea sin proyectar sobre él anacronismos, el texto latino de los Hechos es, en sí, por completo inocuo. En su literalidad, la synagoga libertinorum de la que en él se habla es eso: una sinagoga formada por hijos o descendientes de libertos, que es lo que "libertinos" significa. Hasta que, en el medio calvinista ginebrino de los años cuarenta del siglo XVII, pase a ser situado en el centro de gravedad de una diatriba que tiene como blanco a autores hostiles al reformador y cuyos escritos se han perdido para nosotros casi por completo, "libertino" ha carecido de uso apologético alguno. Los que se oponen a Calvino dentro de la Reforma, se ven endosar ese adjetivo como una marca infamante. Es su adversario quien los define como tales. Sin que nosotros dispongamos de materiales suficientes para fijar a qué autodesignación hubieran preferido ellos acogerse.

\footnotetext{
1 Hechos de los Apóstoles, 6, 9: «Surrexunt autem quídam de Synagoga, quae apellatur Libertinorum, et Cyreniensum, et Alexandrinorum, et eorum quierant a Cilicia et Asia, disputantes cum Stephano».
} 
El primero en haber hecho uso del epíteto parece haber sido Pierre Viret, en carta a Rudolph Gwalter del 5 de septiembre de 1544, en la cual alude al holandés David Joris y, junto a él, quoddam novum Catabaptistarum genus, quos Libertinos vocant ${ }^{2}$. Calvino, pocos meses después, lo retomará en dos escritos del año 1545, que fijarán los términos del debate reformado: la Briève instruction pour armer tous bons fideles contre les erreurs de la secte commune des Anabaptistes ${ }^{3}$ y, sobre todo, el canónico Contre la secte des phantastique et furieuse des libertins, qui se nomment spirituelz.

La primera y la más grave de las dificultades interpretativas que los dos libelos de Calvino plantean es que en ellos "libertino" opera como un epíteto para descalificar al adversario, un adversario formado por autores de cuya obra nada que no sea lo citado por su refutador ha llegado hasta nosotros. De Quentin Thierry y de Antoine Pocquet poco más sabemos que las descalificaciones aquí vertidas por el maestro espiritual de Ginebra. Calvino parece, en diversos pasajes, sugerir que la denominación de "libertino" habría sido una autodefinición deliberadamente adoptada por los propios componentes del grupo («...ceux qui se nomment libertins...», escribe ${ }^{5}$ ), pero resulta imposible rastrear un solo uso del término en esos años que no se ajuste al polémico contenido infamante con que él lo sella al ala extrema del anabaptismo en la primera de sus dos diatribas:

Los anabaptistas se agrupan en dos sectas principales, la primera de las cuales, aun estando llena de muchos errores malos y perniciosos, se ajusta, sin embargo, a una mayor sencillez. Ya que, al menos, acepta la sagrada Escritura como nosotros. Si uno llega a tener trato con los partidarios de ella, sabe en qué difiere de nosotros: dejan oír su concepción y, al final, uno sabe en qué está de acuerdo con ellos y en qué sigue habiendo controversia.

La segunda es un laberinto sin igual de ensoñaciones tan absurdas que es maravilla cómo criaturas que aparentan figura humana puedan estar tan desprovistas de

\footnotetext{
${ }^{2}$ Citado por Margolin, J.-C.: « Réflexions sur l'emploi du terme libertina u XVIIe siècle », en Aspects du libertinisme au XVIIe siècle. Actes du Colloque international de Sommières; París, 1974, 6.

${ }^{3}$ Editada en Ginebra por Iehan Girardi. En adelante, nos referiremos a ella como BI. En esta obra anuncia Calvino cómo «si tengo tiempo de hacerlo, escribiré otro pequeño tratado contra la segunda banda de la cual he hablado, la de los libertinos» (12). «Y, en lo referente a los que se hacen llamar libertinos, que son los más empecinados en todos los sentidos, reservo para ellos otro tratado» (167).

$41^{a}$ edición, 1545, $2^{a}$ ed. 1547. La segunda edición incluye la complementaria Épistre contre un cordelier. Existe una excelente edición crítica, a cargo de Mirjam Van Veen, editada por la Librairie Droz de Ginebra en 2005. Citaremos conforme a esta última edición, a la que nos referiremos en adelante como CSL.

${ }^{5} \mathrm{BI}, 167$.
} 
sentido y de razón como para dejarse engañar de tal manera, hasta caer en fantasías más que brutales. Ésta es la secta que se llama la de los libertinos. Y contradicen tanto a los espirituales que no tienen más cuenta de la palabra de Dios que de la de las fábulas: y, así, cuando bien les parece y pueden la depravan, para forzarla a servir a sus opiniones diabólicas ${ }^{6}$.

Esas opiniones -que el específico tratado, aún en proyecto, habrá de confrontar- se resumen para el Calvino de la Breve instrucción en un tópico de resonancia materialista y epicúrea: «querer hacer a los hombres similares a las bestias brutas»"7, eliminando con ello toda dignidad moral del alma humana, toda esa jerarquía cristiana de valores que se asienta sobre la afirmación del bien y la negación del mal:

Los principios de los libertinos consisten en confundir toda diferencia entre bien y mal, en mezclar a Dios con el Diablo, hasta tal punto que no se sepa ya diferenciar entre uno y otro, y en hacer a los hombres, no sólo estúpidos ante Dios en sus conciencias, sino también desvergonzados ante el mundo. Y ésta es la razón por la cual se ocultan en cavernas de palabras vanas y enigmáticas ${ }^{8}$.

Lo que, en 1945, Calvino llama "libertinos", tiene en su descripción todos los caracteres de una secta o comunidad religiosa. Si no los de una iglesia. Vanidad de esos anabaptistas radicales que describe el proceso de Loy Pruystinck un año antes y que han arraigado en zonas muy precisas de la Europa reformada: Amberes, Brabante y Flandes, bajo lo que es descrito cómo libertini a carnis libertate, qua millorum doctrina permitere videtur, appellantur ${ }^{9}$. Y quizá lo que más preocupe a Calvino sea que esos anabaptistas radicales han logrado una nada despreciable influencia en la corte, en Nérac, de Margarita de Navarra, madre del rey de Francia, Francisco I, con la cual él mismo se sabe en deuda.

Contre la secte des phantastique et furieuse des libertins, qui se nomment spirituelz. fija los términos acabados de una polémica cuya otra orilla nos va a permanecer ignota. Dibuja el extraño retrato de una "secta" a la cual definen "fantasía" y "furor", encubiertos bajo

\footnotetext{
${ }^{6} \mathrm{BI}, 9-10$.

${ }^{7} \mathrm{BI}, 11$.

${ }^{8} \mathrm{BI}, 10$.

${ }^{9}$ El proceso de Loy Pruystenick, entre julio y octubre de 1544, es analizado por Margolin en su trabajo más atrás citado.
} 
máscara de una "espiritualidad” que no es, para Calvino, mucho más que enrevesada versión del "panteísmo popular"10 que latiera en las primeras herejías cristianas.

La "secta" aparece ya señalada en la carta que envía a Calvino Valérand Poullain desde Estrasburgo el 26 de mayo de 1544: "Nuestros hermanos de Velenciennes, que nos habían traído recientemente los escritos de los quintinistas, se han vuelto a casa. Si has leído lo que te envié, te suplico por Cristo que tengas la bondad de escribirles unas palabras de consuelo para sostenerlos en sus grandes miserias y para fortificarlos y sostenerlos contra esas pestes"11.

En su segundo escrito, Calvino da los nombres de quienes serían los maestros espirituales de la secta: de un tal Coppin, de Lille, nada sabemos; de los otros dos, Quintin Thiery ${ }^{12}$ y Antoine Pocque, muy poco. Ambos son huéspedes de la reina Margarita, quien parece haber apreciado mal el exceso de celo de Calvino contra sus protegidos. Sólo de Pocque (o Pocquet) conservamos un pasaje lo bastante largo como para hacernos una idea, siquiera aproximada, de sus posiciones: precisamente el que Calvino reproduce, para refutarlo, en el capítulo 23 de su libro ${ }^{13}$. Obligados como estamos a reconstruir sus tesis sobre la única base de una refutación furibunda y bajo una calificación -la de "libertinos"- que ni siquiera podemos constatar si ellos utilizaron, la exposición de qué sean esos "libertinos espirituales" debe quedarse en una hipótesis de verosimilitud dudosa. Lo que ese nombre hace resonar en la cabeza del reformador cristiano que lo esgrime tiene, sin embargo, un interés mayor para fijar las fantasmagorías frente a las cuales el cristianismo moderno trata de configurarse.

\section{Calvino contra la secta fantástica}

10 Entrecomillo la expresión porque, por supuesto, es un anacronismo. Panteísmo y panteísta son expresiones cuyo nacimiento está fechado. John Toland hace uso de ellas por primera vez, respectivamente en los años 1704 y 1705. Con la expresión "panteísmo popular" es común hacer referencia a formas de religiosidad que amalgaman cristianismo y neoplatonismo en los primeros siglos de nuestra era. Su continuidad, como corriente subterránea del monoteísmo, puede ser rastreada hasta bien entrada la edad moderna.

${ }^{11}$ En Calvin: CEuvres; París, Gallimard-Pléiade, 2009, 1305.

12 Quintin Thiery fue ejecutado como hereje en Tournai el 24 de diciembre de 1546. Calvino, en la Épitre contre un Cordelier, que añade a la edición de 1547 de CSL, reivindica el papel de su panfleto en una condena que había reposado, dice, «tanto sobre testigos cuanto sobre mi libro, del cual la justicia, aun cuando fuera para desdicha, se sirvió». La Epístola está fechada el 20 de agosto de 1547.

13 CSL, 144-163. 
No hay nada peor que un libertino. Ni siquiera un Papa. Para Calvino y en 1545. Pues «incluso el Papa deja en pie alguna forma de religión. No arrebata la esperanza de la vida eterna. Enseña a temer a Dios. Pone alguna distinción entre el bien y el mal. Reconoce a nuestro Señor Jesús como verdadero Dios y verdadero hombre. Atribuye autoridad a la palabra de Dios» ${ }^{14}$. Muy nefando habrá de ser el adversario para que, contrapuesto a él, incluso la prostituta romana parezca hasta cierto punto virtuosa.

En el límite, la del Papa es herejía. Cristianismo, pues. Los libertinos entroncan con una anticristianismo frontal: el de ese epicureísmo pagano, en el cual la excelencia anímica se volatiliza. «Todo el objetivo suyo está en amalgamar cielo y tierra, aniquilar toda religión, borrar todo conocimiento del intelecto de los hombres, amortajar las conciencias y no mantener diferencia alguna entre los hombres y las bestias» ${ }^{15}$. El monismo que proclama esta secta libertina, al pretender que todo cristiano verdadero quede absorbido en Dios, oculta apenas la destrucción de la inmortalidad individual de las almas que así consuma.

Es, para Calvino, el primer artículo de la doctrina de los libertinos: «que no hay más que un espíritu, y que éste es inmortal» ${ }^{16}$ : Dios. Que en él son todos cuantos cristianos. Y que todo cuanto está permitido a Dios -o sea, todo-, está en idéntica medida permitido a los que son en él. Que no hay, en suma, «más que un solo espíritu, el de Dios, que es y vive en todas sus criaturas. Por este medio, aniquilan [anéantissent] la esencia, tanto de las almas humanas cuanto de las naturalezas angélicas» ${ }^{17}$.

Calvino -que ha señalado ya en 1543 cómo fuit illa quidem olim Sadducseorum opinio ${ }^{18}$ - no se engaña sobre el origen pagano de tal tesis:

Cierto es que algunos hubo entre los antiguos filósofos lo bastante fantasiosos como para imaginar que no haya más que un solo espíritu, que se extiende por todo, y que todas las criaturas vivas y poseedoras de movimiento y sentimiento no son más que porciones que de él proceden y a él retornan ${ }^{19}$.

\footnotetext{
${ }^{14}$ CSL, 60.

${ }^{15}$ Ibid.

16 CSL, 82.

17 Ibid.

18 Inst. (1543), I. 14. 9.

${ }^{19}$ CSL, 82.
} 
Esa certeza de tener que vérselas con un nuevo paganismo guía la estrategia de Calvino contra los libertinos de su tiempo, a los cuales busca el único verosímil origen en las más viejas herejías del primer cristianismo, aquellas en las cuales el imaginario precristiano se trasluce más evidentemente. Contra eso, el anfitrión de Calvino en Ginebra, Guillaume Farel, había llamado ya, en 1550, a prevenir a los buenos cristianos, al tiempo que enfatizaba cómo, contra la sagrada Escritura, «tanto los Anabaptistas como los Libertinos, Epicúreos y todo tipo de descarriados se envuelven en esa cantinela suya de la misosofía ${ }^{20}{ }^{21}$. Se trata de un gremio formado por aquellos que «no tienen otro odios que no sea el de las verdaderas sabiduría y ciencia» ${ }^{22}$, sigue Farel. Parece preocuparle muy seriamente la hipótesis de que «Satán puede hacer ese complot con todas estas pestilentes e infames criaturas» ${ }^{23}$. Con las fatales consecuencias que eso acarrearía a la comunidad cristiana. Es lo que su discípulo Pierre Viret remachará en el tercer diálogo de su Interim fait par Dialogues del año 1655:

El supersticioso y el idólatra y el ignorante y el inválido están casi más cerca de la verdadera religión que el Ateo, el Epicúreo y el Libertino... En cuanto a su conciencia, [los libertinos] carecían de ella, no en manera menor que los Epicúreos y los Ateos. Mas, no obstante, se resistían con fuerza y dureza a la verdad, y mantenían obstinadamente la doctrina del Anticristo y las tradiciones humanas ${ }^{24}$.

Théodore de Bèze hará remontar el origen de tal aberración al retorno de la oscura secta antigua de los carpocracianos: sería en 1533 y en París en donde habría dado señal primera de vida la secta de los libertinos, «los cuales, en nuestro tiempo, renovaron la abominable secta de los Carpocracianos, negando toda diferencia entre bien y mal» 25 .

Calvino retoma la genealogía sobre el origen de los libertinos de su tiempo en ese punto: gnosis y carpocracismo, la confusa frontera del primer cristianismo con las brumas paganas:

\footnotetext{
${ }^{20}$ Odio o rechazo de la sabiduría. El neologismo busca la contraposición a "filosofía".

${ }^{21}$ Guillaume Farrel: La glaive de la parolle, 1550, 222 y 451. Citado en Margolin, loc. cit.,15.

22 Ibid.

${ }^{23}$ Ibid.

${ }^{24}$ Intérim fait par dialogues, III. Cito siguiendo la edición de Guy R. Mermier, Nueva York, Berna, Frankfurt, Peter Lang, 1985, 114.

${ }_{25}$ Histoireécclesiastique, Anvers, 1580, 14.
} 
Nos hemos referido ya a ciertas sectas que en el pasado perturbaron a la iglesia cristiana con ensoñaciones, si no completamente idénticas, sí muy semejantes. Que las almas y espíritus celestes eran tan de la substancia misma de Dios como un carbón encendido por el fuego. Ahora bien, los libertinos, con el fin de superar en impudor a todos los herejes que jamás fueron, han retornado a esta antigua imaginación de los paganos: que no hay más que un solo espíritu que está en todo 26.

Absortos por la redención en el único espíritu divino, los libertinos así descritos habrían necesariamente de hacer la economía de un libre albedrío que sólo podría, en rigor, ser pensable suponiéndole un marco individual ontológicamente independiente de la determinación divina. Los libertinos, a los que fulmina Calvino, «no atribuyen al hombre ninguna voluntad, en no distinta medida a lo que sucede con una piedra, y abolen toda distinción entre el bien y el mal, puesto que nada puede estar para ellos mal hecho, siendo Dios, como lo es, su autor» ${ }^{27}$. El peligro que se subraya en tales tesis doctrinales es primordial: al eliminar la voluntad libre, mérito y demérito dejan de jugar papel alguno en la actuación del cristiano. El sacrificio de la cruz pierde sentido, como pierden cualquier proyección eterna recompensa y pena por lo actuado. Infierno y cielo se desvanecen. Y la figura del Cristo Salvador resulta ociosa.

Calvino enfatiza la gravedad del laxismo moral que de ello derivaría, con un anecdotario francamente pedestre acerca de los cabecillas de la secta. Y roza, en ello, la vulgaridad del chascarrillo aldeano. Así, cuando narra el ridículo avatar de Quintin Thierry confrontado a uno de sus seguidores que había llevado hasta la coherencia inocente del crimen la tesis de su maestro que, al identificar plenamente a cada cristiano con Dios, lo exime de cualquier constricción mundana:

Con el fin de que las cosas sean aún con más facilidad entendidas, alegaré algún ejemplo de sus palabras. Este pedazo de rústico de Quintin se hallaba una vez en una calle donde un hombre había sido matado. Había por ventura allí un fiel que dijo: ¡Ay! ¿Quién ha cometido este malvado acto? De inmediato, respondió en su jerga ${ }^{28}$ : Puesto que quieres saberlo, yo he sido. Del todo asombrado, respondiole el otro: ¿YY cómo habéis podido ser

\footnotetext{
${ }^{26}$ CSL, 83.

${ }^{27}$ CSL, 89.

${ }^{28}$ El pasaje original reproduce los usos de un dialecto popular de efecto buscadamente cómico e intraducible.
} 
tan cobarde? A lo cual replicó él: No yo, sino Dios. ¿Cómo?, dijo el otro, ¿habrá que imputar a Dios los crímenes que el ordena que sean castigados? A lo cual este sinvergüenza vomitó el más moral de los venenos, diciendo: Sí, es ti, es mí, es Dios. Pues lo que tú y yo hacemos, es Dios quien lo hace, y lo que Dios hace, nosotros lo hacemos, porque Él es en nosotros. Concedido ese punto, o bien habrá que imputar a Dios el pecado, o bien concluir que no hay pecado alguno en el mundo, visto que no hay nada que Dios no haga... Y, puesto que Dios lo hace todo, nada de ser considerado malo ${ }^{29}$.

La deriva de un tal "gnosticismo cristiano" arrastraría hacia una anacrónica variedad de “panteísmo popular”, que -en la versión que de él nos da Calvino, al menos- habría tomado formas de neoplatonismo espontáneo muy extremas, en las cuales resonarían los ecos de algunas de las más peligrosas primeras herejías cristianas:

En cuanto a Dios y a la substancia de las almas, aun cuando [los libertinos] no hablan exactamente igual que los maniqueos, todo cuanto rumian entre sus dientes se resume en esto: que no hay más que un espíritu que es Dios; y, del otro lado, el mundo; que las criaturas, todas ellas, no son nada, sino que el espíritu de Dios, al estar entre los hombres, las mantiene hasta que de ellas se retira; y que cuanto tienen fuera de eso es mundo, o Satán, o nada. Si un hombre es de su secta, lo hacen Dios, diciendo que su alma es el espíritu de Dios; si no, no lo tienen más en cuenta que a un caballo, porque en él no hay más que mundo, que es nada ${ }^{30}$.

El riesgo mayor de ese "panteísmo popular", cuyos rebrotes en la historia del cristianismo han sido continuos, desde los primeros siglos hasta la edad moderna, resulta transparente: si todo fuera Dios, como en la gnóstica continuidad de los libertinos dice Calvino haber sido postulado, entonces el lugar de la inmortalidad y la resurrección individuales habrían perdido función alguna. En rigor, la salvación habría ya acaecido en la muerte y resurrección de Cristo como acontecimiento absoluto. Para todos cuantos cristianos. Así lo señala el Contra la secta fantástica y furiosa de los libertinos, recurriendo a la exégesis del mismo San Pablo a cuya autoridad habrían recurrido los libertinos ginebrinos con la mayor frecuencia, según el texto de Calvino:

\footnotetext{
${ }^{29}$ CSL, 89-91.

${ }^{30}$ CSL, 54.
} 
San Pablo hace mención de Phileto e Hymeneo, quienes ya en sus tiempos decían que la resurrección había sucedido... [Los libertinos] se burlan de toda la esperanza que tenemos en resucitar, diciendo que todo lo que esperamos ha sucedido ya... ; que Jesucristo, por su muerte, ha abolido la vanidad [le cuider], y por este medio nos ha restituido la vida, que consiste en conocer que no morimos... Pero, ¿a quién persuadirán de que el significado de las palabras [del Eclesiastés] sea el de que el alma humana, retornando a Dios, sea $\operatorname{Dios}^{31}$.

En esa participación gnóstica en la realidad divina, cifra Calvino la gravedad la heterodoxia de esos libertinos, que «nos arrebatan [ostent] el principal punto de nuestra cristiandad ${ }^{32}$.

¿Dónde nació el problema? ¿De dónde viene el delirio de “esos puercos” que, «con su gruñido ponen boca abajo la doctrina [cristiana], diciendo que nada falta ya, una vez que la vanidad [le cuider] ha sido abolida, y que basta con que el espíritu se vuelva hacia Dios, escapando del cuerpo» ${ }^{33}$ ?

Contra esos tales es contra quienes -dice Calvino- había escrito San Judas en su "epístola universal”, subrayando, al hacerlo, cuan necesario juzgó escribir a la atención de estos que se hacen llamar santificados en Dios Padre y preservados en Jesucristo,

acerca de nuestra común salvación, cuan necesario escribiros exhortándoos a que contendáis ardientemente por la fe que ha sido una vez dada a los santos. Porque algunos hombres han entrado encubiertamente: los que desde antes habían sido destinados para esta condenación, hombres impíos, que convierten en lujuria la gracia de nuestro Dios, y niegan a Dios, el único soberano, y a nuestro señor Jesucristo ${ }^{34}$.

\footnotetext{
${ }^{31}$ CSL, 137-138.

32 CSL, 141.

33 Ibid.

${ }^{34}$ Judas, E3-4: Carissimi, omnem sollicitudinem faciens scribendi vobis de communi nostra salute, necesse habui scribere vobis, deprecans certare pro semel tradita sanctis fide. Sub introierunt enim quidam homines, qui olim praescripti sunt in boc iudicium, impii, Dei nostri gratiam transferentes in luxuriam, et solum Dominatorem et Dominatum nostrum Iesum Christum negantes. En la traducción de Cantera-Iglesias que venimos utlizando: «Queridos, cuando estaba con todo interés por escribiros acerca de nuestra común salvación, me he visto obligado a hacerlo, exhortándoos a luchar por la fe que se les transmitió a los santos de una vez para siempre; pues se han infiltrado subrepticiamente unos hombres que hace tiempo están apuntados de antemano para esta condena, impíos que cambian la gracia de nuestro Dios en libertinaje, y niegan a nuestro único Amo y Señor, Jesucristo». Debo apuntar sólo que la traducción de luxuria por libertinaje me parece anacrónica.
} 
A dos referencias evangélicas remite, pues, Calvino los orígenes de la doctrina "libertina", a la cual el busca erradicar definitivamente:

a) el pasaje de los Hechos de los apóstoles en el cual se alza constancia de una “sinagoga de libertinos" (esto es, de "hijos o descendientes de libertos") que se había enfrentado a la predicación de San Esteban, y

b) la admonición de la epístola de San Judas contra estos "hombres impíos, que convierten en lujuria [luxuriam, aunque los traductores modernos lo traduzcan frecuentemente por libertinaje] la gracia de nuestro Dios".

No es mucho. Pero la autoridad de ambas fuentes es lo bastante sólida como para hacernos dudar de que los interlocutores de Calvino hayan podido adoptar por decisión propia una denominación tan ofensivamente rechazada por la suprema autoridad fundacional de los discípulos directos de Cristo. Es muy poco verosímil que el término "libertino" haya tenido jamás carácter autodesignativo. Menos aún autodefinitorio. Desde el principio, se trata de un epíteto despectivo, que sólo puede provenir de quienes tratan de desprestigiarlos ante la comunidad cristiana. El contenido, así, de las doctrinas que les son atribuidas queda contaminado por esa proyección valorativa: con la mayor verosimilitud, lo que Calvino y sus seguidores presentan como doctrina libertina no puede ser otra cosa que un dossier específicamente fabricado para su refutación. Y, a través de ella, para consolidar la autoridad única de la Reforma ginebrina.

\section{Usos de San Pablo}

La autoridad apostólica es aquí reivindicada por Calvino como instrumento para poner freno a un relativismo moral del cual podrían derivarse loa mayores riesgos a los cuales se enfrenta la comunidad cristiana: los que laten en la interpretación del sacrificio de Cristo como definitiva victoria sobre el mal y final abolición del pecado. Para el reformador de Ginebra, estaríamos ante una de las corrientes heréticas de más larga y reiterada vida en la historia del cristianismo. Una herejía contra la cual habrían combatido Apóstoles y Padres de la Iglesia, y cuya plasticidad le habría permitido, a lo largo de dieciséis siglos, recomponer sus tesis básicas, en torno a la inconsistencia del bien y del mal una vez acaecida la mutación ontológica que es la redención: 
Se puede ver, por la segunda epístola de San Pedro y por la de San Judas, que ya por aquellos tiempos había una secta de malvados que, bajo nombre de cristiandad, inducían a los simples a la vida disoluta, eliminando la discriminación entre el bien y el mal y aletargando las conciencias con halagos, con el fin de que sin el menor escrúpulo viviera cada cual a su apetito, abusando de la libertad cristiana para dar rienda suelta a toda licencia carnal, complaciéndose en traer la confusión al mundo, poniendo boca abajo toda policía, orden y honestidad humanos... [De ese modo, los libertinos] no hicieron otra cosa que resucitar esas viejas herejías que yo he enunciado [gnósticos, valentinianos y maniqueos], tomando de cada una algún fragmento para construir con él una escombrera de confusión ${ }^{35}$.

Calvino rastrea el libro I del Adversus Haereses, escrito por San Ireneo en el año 180 de la era cristiana, para dar con la pista de los orígenes paleocristianos de estos presentes «libertinos, que no sólo hacen al diablo compañero de Dios, sino que lo transmutan en Dios, haciendo sus obras dignas de alabanza, so criterio de que no hace más que aquello que Dios le ha ordenado» ${ }^{36}$. En la exposición que hace el obispo de Lyon de las tesis heréticas conducentes al valentinismo, cree reconocer Calvino el germen de una herejía identificable con las palabras de sus propios contemporáneos Quintin Thierry y Antoine Pocque: una abolición simultánea de las categorías de bien y mal que, «si creemos a los antiguos doctores, tomó su origen en Simón el Mago» ${ }^{37}$.

La sombra de Simón de Gitta -o Simón de Samaria o, más popularmente, Simón el Mago-, a modo de reverso tenebroso del San Pablo con el cual algún comentarista actual lo identifica históricamente ${ }^{38}$, ha acompañado a buena parte de las herejías cristianas. Desde su aparición en los Hechos de los Apóstoles, inmediatamente después de la narración de las persecuciones anticristianas cometidas por Saulo antes de su conversión y culminada en el martirio de San Esteban:

Saulo, por su parte, aprobaba su asesinato [el de San Esteban mediante lapidación]. Aquel día hubo una gran persecución contra la iglesia de Jerusalén; todos se dispersaron, menos los

\footnotetext{
${ }^{35}$ CSL, 49 y 53.

36 CSL, 97.

${ }^{37}$ Ibid.

${ }^{38}$ Cfr. HermannDetering: Thefabricated Paul. Early Christianty in the Twilight, ed. digital, 2012, y Günther Bornkamm: Pablo de Tarso; Barcelona, Sígueme, 2002.
} 
apóstoles, por las regiones de Judea y Samaría. Hombres religiosos llevaron a enterrar a Estaeban e hicieron gran duelo por él. Saulo, por su parte, devastaban la Iglesia, entrando por las casas; y arrastrando a hombres y mujeres los mandaba a la cárcel.

Así, pues, los que se habían dispersado fueron de acá para allá predicando la Palabra. Felipe, bajando a la ciudad de Samaría les predicaba al Mesías. El gentío, unánimemente, prestaba atención a lo que decía Felipe, al oír y ver las ‘señales' que realizaba: pues de muchos de los que tenían espíritus impuros salían éstos dando alaridos, y muchos paralíticos y cojos se curaban. Hubo gran alegría en aquella ciudad.

Uno, por nombre Simón, había practicado la magia en la ciudad anteriormente y asombrado al pueblo de Samaría diciendo que él era alguien importante; todos le prestaban atención, chicos y grandes, diciendo: 'Éste es la fuerza de Dios que se llama grande’.

Le prestaban atención por haberlos asombrado mucho tiempo con los encantamientos. Pero cuando creyeron a Felipe, que predicaba el evangelio del reino de Dios y del nombre de Jesucristo, hombres y mujeres se bautizaban. Y también Simón abrazó la fe, y, una vez bautizado, estaba continuamente al lado de Felipe, y se asombraba al ver las 'señales' y grandes prodigios realizados.

Cuando los apóstoles que estaban en Jerusalén oyeron que Samaría había acogido la palabra de Dios, les enviaron a Pedro y Juan, que bajaron y rezaron por ellos, para que recibieran al Espíritu Santo (pues todavía no había descendido sobre ninguno de ellos, sino que sólo se habían bautizado en el nombre del Señor Jesús.) Entonces iban imponiéndoles las manos y recibían al Espíritu Santo. Al ver Simón que se daba el Espíritu Santo por la imposición de las manos de los apóstoles, les ofreció una cantidad, diciendo: 'Dadme también a mí ese poder: que al que le imponga yo las manos reciba al Espíritu Santo’.

Pero Pedro le dijo: 'iQue tu dinero se vaya contigo a la perdición, porque creíste poder comprar con dinero el don de Dios! No tienes tú porción ni parte en este punto, pues tu corazón no es recto ante Dios. Así que arrepiéntete de esa malicia tuya y pídele a Dios a ver si acaso se te perdona esa quimera de tu corazón, pues veo que estás envenenado con hiel y maniatado por la iniquidad' 
Simón respondió así: 'Pedid vosotros por mí al Señor para que no me venga encima nada de lo que habéis dicho’.

Así es que ellos, después de dar testimonio y haber expuesto la palabra del Señor, volvían a Jerusalén, y evangelizaban muchas aldeas de los samaritanos ${ }^{39}$.

Aunque el pasaje de Hechos se cierra con la aparente reconciliación de un Simón arrepentido, la leyenda de perversidad -y de búsqueda de rentabilizar mundanamente los sacramentos- se anudará en torno al nombre del personaje de un modo indeleble. Es de lo que da cuenta la reflexión de San Ireneo en el siglo segundo, al considerarlo el protohereje por excelencia. La sección II del Libro I de Adversus Haereses recupera su trayectoria allá donde la abandona el relato de los Hechos. Inmediatamente después de la admonición de San Pedro. Tras de la cual, anota Ireneo, Simón «creyó todavía menos en Dios y le invadió el deseo de querellarse contra los apóstoles para parecer también él digno de gloria. Entonces se entregó con más ahínco al estudio de toda el arte mágica, maravillando a muchos hombres hasta tal punto que, según se dice, también el emperador Claudio, bajo cuyo imperio vivió, le dedicó una estatua a causa de sus artes mágicas» ${ }^{40}$.

La mitologización de Simón el Mago parece haber hecho ya buena parte de su camino en el temprano momento del siglo II en que San Ireneo da cuenta del retrato fuertemente deificado que de él dan sus discípulos:

Simón ha sido glorificado por muchos como Dios. Si bien había aparecido como Hijo entre los judíos, había descendido a Samaria como Padre y había venido a las demás naciones como Espíritu Santo, afirmaba que él era la Potencia altísima, es decir, el Padre que está sobre todas las cosas, aunque toleraba ser invocado por los hombres bajo variadas denominaciones ${ }^{41}$.

La doctrina simoniana, de la cual Ireneo de Lyon da cuenta, aparece a todos como una reelaboración del relato de la unión del profeta Oseas con la prostituta Gomer por mandato divino. Amalgamada a una angelología de matriz neoplatónica y muy

\footnotetext{
${ }^{39}$ Hechos, 8, 1-24.

40 Los gnósticos, vol. I, edición de J. Montserrat, Madrid, Gredos, 1983, 198.

${ }^{41}$ Los gnósticos, vol. I, ed. cit., 199.
} 
contaminada por los ritos fenicios de Astarté. La transcribo aquí, tal cual, del Adversus Haereses ireneano:

He aquí la doctrina de la secta de Simón samaritano, de la que procedieron todas las herejías. Simón rescató a una prostituta llamada Helena en Tiro de Fenicia, y la llevaba consigo diciendo que era el Primer Pensamiento (Énnoia) de su mente, madre del universo, por medio de la cual al principio había pensado hacer a los ángeles y arcángeles. Este Pensamiento, surgiendo de él y sabiendo lo que quería su Padre, descendió a las cosas de abajo y engendró a los ángeles y potestades, por los cuales fue creado este mundo. Una vez engendrado, retuvieron a Énnoia por envidia, ya que no quisieron que se les tuviese por progenie de algún otro. Efectivamente, desconocían en absoluto la existencia de Simón, quedando Énnoia retenida por las potestades y los ángeles que había emitido, quienes le hicieron sufrir toda clase de vejámenes para que no se remontase hacia su Padre; hasta tal punto que la encerraron en un cuerpo humano y estuvo siglos enteros transmigrando de un cuerpo de mujer a otro, como en un continuo trasvase. De este modo, se encontraba en aquella Helena que fue causa de la guerra de Troya, y así se explica que Estesícoro, por difamarla en sus versos, quedara ciego, y que, cuando se arrepintió y escribió en su alabanza las Palinodias, recobrara la vista. Transmigrando de cuerpo en cuerpo, sufriendo siempre vejaciones por esta causa, vino a parar de prostituta en un burdel -y esta es la oveja perdida.

Por esto vino Simón, con el fin de recogerla la primera y librarla de sus cadenas, y con el fin también de otorgar la salvación a los hombres por medio de la conciencia de sí mismos. Dado que los ángeles gobernaban mal el mundo, vino para enderezar este estado de cosas, y descendió transmudado de aspecto y hecho semejante a los principados y a las potestades y a los ángeles, hasta aparecer como hombre entre los hombres, aun sin ser él mismo hombre. Y se creyó que había sufrido pasión en Judea, cuando de hecho no la sufrió. Los profetas pronunciaron sus profecías inspirados por los ángeles creadores del mundo; por esto los que han puesto su esperanza en él y en su Helena no se preocupan ya más de los profetas y, a fuer de libres, hacen lo que quieren. Los hombres se salvan por la gracia de Simón, no por mérito de sus buenas obras, ya que no se dan acciones justas por naturaleza, sino sólo por convención. Así los establecieron los ángeles que hicieron el mundo, que esclavizaron a los hombres por medio de aquellos preceptos. Por lo cual, Simón prometió que el mundo sería destruido y que los suyos serían liberados del dominio de los que lo crearon. 
En consecuencia, los sacerdotes de sus misterios viven en la lujuria, practicando las artes mágicas cada uno como puede. Utilizan exorcismos y encantamientos; se entregan a filtros amorosos y excitantes, a los espíritus demoníacos e inductores de sueños, y a toda clase de artes mágicas. Poseen una estatua de Simón que reproduce la figura de Júpiter, y otra de Helena en figura de Minerva, y las adoran. Se les llama simonianos, del nombre de Simón, iniciador de su impísima doctrina; en ellos tuvo inicio el falso conocimiento, según se deduce de sus mismas afirmaciones ${ }^{42}$.

\section{Después del pecado}

Lo que en ese cuadro que Ireneo traza sostiene la atención polemista de Calvino es claro: la clave paradojista de la herejía, que hace diluirse en una sola entidad bien y mal, mérito y pecado, cielo e infierno, Dios y Diablo. Ahí, en esa brutal anacronía, estaría el corazón del libertinismo. «¿Qué es lo que los libertinos consideran acerca del diablo, del mundo y del hombre...?» ${ }^{43}$, se pregunta al capítulo doce del Contra la secta furiosa de los libertinos. -La más extravagente amalgama, se responde a sí mismo. Mundo, hombre y diablo son en ella indistinguibles. Y, lo que es más grave, indiscernible Dios:

Alguien preguntará, llegados aquí, qué opinión tienen, pues, [los libertinos] del diablo. Yo respondo que lo nombran y hablan de él, pero que lo hacen sólo en su propio sentido. Pues toman diablo mundo y pecado por una imaginación que nada es, y dicen que tal sucede con el hombre hasta que haya sido refundido en su secta ${ }^{44}$.

No hay pecado cuando la redención ha sido hecha. Eso habrían enseñado los herejes a los cuales da Calvino una batalla en la cual ve jugarse el destino de la cristiandad. Hay una lógica blindada, reconoce, en el planteamiento de esos a los que él ha llamado libertinos: ¿en qué quedaría el sacrificio de un Dios que ni siquiera hubiera logrado abolir el mal del mundo? Y, ¿cómo, en un mundo por Cristo redimido, distinguir entre lo que nosotros somos - cada uno de nosotros es- de aquello en lo cual el cuerpo místico de Cristo nos

\footnotetext{
${ }^{42}$ Los gnósticos, vol. I, ed. cit., 200-204.

${ }^{43}$ CSL, 86.

${ }^{44}$ Ibid.
} 
transmuta? Los libertinos «dicen que Jesucristo abolió el pecado... Y, según su fantasía, somos todos Cristos y lo que se hizo en él se hízose en todos» ${ }^{45}$.

El verdadero problema nace al constatar cuál es el fundamento de autoridad sobre el cual alza el libertinismo su edificio doctrinario: San Pablo. El San Pablo, en particular, pero no sólo, de la Epístola a los romanos, que instruye acerca de cómo «el viejo hombre en nosotros fue crucificado juntamente con Cristo, para que el cuerpo del pecado fuera destruido, a fin de que no viviéramos más en el pecado. Porque el que ha muerto, ha sido justificado por el pecado» ${ }^{46}$.

La tesis fundacional del libertinismo que Calvino combate se situaría en ese punto de partida. Y eso lo haría tanto más peligroso cuanto más fácilmente camuflable bajo la ortodoxia paulina:

[Los libertinos] confiesan, con nosotros, que no podemos ser hijos de Dios sin haber antes renacido... Y, de hecho, cuando se oye resonar esas palabras en su boca, según las cuales, si somos de Dios, es necesario que el hombre viejo sea crucificado en nosotros ${ }^{47}$, que el viejo Adán muera, que nuestra carne sea mortificada, que el mundos sea destruido, que en él no reine ya nunca más el pecado, ¿quién podrá evitar ser engañado?... La impudicia de esos malvados [consiste] en osar depravar así la escritura ${ }^{48}$.

Pero, una vez que el "nuevo nacer" ha sido consumado y que, muerto el Adán que fuimos, todo se vuelva en nosotros Cristo, son los fundamentos ontológicos del pecado los que quedan, de inmediato, reducidos a nada. De ahí esa actitud, que Calvino execra, pero cuya coherencia está cristológicamente blindada, en el nuevo gnosticismo libertino, que «a aquellos que ningún caso hacen ya del pecado, llaman criaturas nuevas, porque están libres de la vanidad [du cuider] y, por ello, no tienen ya pecado en ellas. Y en ello hacen consistir todo el beneficio de la redención llevada a cabo por Jesucristo, ya que él destruyó esa vanidad [cuider] que había entrado en el mundo por la culpa de Adán.

\footnotetext{
${ }^{45}$ CSL, 108-109.

46 Rom. 6, 6-7.

${ }^{47}$ Rom. 6, 6.

48 CSL, 111-112.
} 
Cuando esa vanidad [cuider] es abolida, no hay ya diablo ni mundo, según su opinión. Pues tal es el único enemigo que los atormenta» ${ }^{49}$.

Lo cual, por más sospechas de aberración que levante en el devoto, es lo que de la literalidad de la Epistola a los Romanos paulina parece desprenderse, allá donde declara cómo «no soy yo quien hace el mal, sino que lo hace el pecado que mora en mí» ${ }^{50}$. Lo que, con igual contundencia, comunica la Primera Epistola de San Juan en defensa de los fieles contra el esfuerzo vano de Satán:

El que practica el pecado es el diablo; porque el diablo peca desde el principio. Para eso vino el Hijo de Dios: para deshacer las obras del diablo. Todo aquel que es nacido de Dios no practica el pecado, porque la semilla de Dios permanece en él; y no puede pecar porque es nacido de Dios $^{51}$.

El enfado de Calvino ante el uso literal que de esos textos están haciendo los libertinos revela una incomodidad muy lógica: la de ver bascular a los apóstoles mismos -y, ante todo, a San Pablo- del lado de las primeras herejías. «Estos fantasiosos, para aprobar su error, se arman con la sentencia de San Juan, según la cual nadie nacido de Dios peca» ${ }^{52}$, se escandaliza el reformador de Ginebra. Pero con ninguna exégesis alternativa va a dar para salir con éxito del atolladero.

Las páginas que siguen a esa constancia de cómo el libertino hace parapeto indiferenciado de todo pasaje apostólico son, en la irritación misma de Calvino, confesión de una derrota. A partir de la cual, su tono se hace más agrio y más amenazante: no se trata ya de discutir conceptos ni de santificar doctrina; se trata de amurallar disciplinariamente la comunidad piadosa frente a una abominación que fatalmente la descompondría, la de esos que «extienden... la libertad cristiana para hacerle al hombre lícito todo, sin excepción... Esos enragés dejan brida suelta al hombre, a fin de que nada ya lo retenga... Esos frenéticos abolen toda ley sin distinción alguna, diciendo que no hay ya que atenerse a ella, puesto que de ella fuimos liberados... Esta

\footnotetext{
49 CSL, 112-113.

50 Rom. 7, 17.

511 San Juan, 3, 8-9.

52 CSL, 117.
} 
liberación nos es dada en el evangelio, cuando se nos dice que estamos bajo la ley... Y esos frenéticos entienden por tales palabras que la ley ha sido abolida por completo» ${ }^{53}$.

Él no trata de ocultar esos pasajes. Demasiado explícitos son, sobre todo, en el San Pablo que llama a los cristianos a asumir cómo «todas las cosas les son lícitas» ${ }^{54}$. Lo que él trata de oponer a los nuevos herejes es una lectura mucho más mesurada de esos textos, con los cuales «estos demoníacos construyen una sentencia general, pretendiendo, bajo tal cobertura, que nada le está prohibido al hombre cristiano... Esas bestias salvajes quieren inferir de ello que todo, sin excepción, nos es lícito... [Y, así, borran toda diferencia entre el bien y el mal» ${ }^{55}$.

La intención apologética de Calvino es clara ${ }^{56}$. Podría, si se quiere, parecer laudable. O al contrario. Pero, que «todo me es lícito» no es interpretación libertina del apóstol. Es el enunciado literal de la Primera a los Corintios. Y no resulta fácil eludir el choque con ese muro. Sin que la sospecha gnóstica, algunas de cuyas corrientes han querido ver en Saulo de Tarso y Simón el Mago al mismo hombre, reaparezca. «Es lo que sucede con ese fantástico abuso de lo que se dice en Romanos, 8: a saber, que no hay ya condenación para los que están en Jesucristo ${ }^{57}$, los cuales viven conforme al espíritu y no conforme a la carne. En lo cual se ve cómo se burlan de la escritura al modo en que lo haría un malvado epicúreo» ${ }^{58}$.

Libertinos, epicúreos, ateos, en suma, que se burlan de la Escritura. El tópico está ya constituido en este año 1547 en el cual Johannes Calvino da a la imprenta, como apéndice de la segunda edición del Contra la secta de los libertinos, su Carta contra un franciscano, que formula abiertamente esa sentencia contra quienes «se burlan de la escritura al modo en que lo haría un malvado epicúreo». Y ese vocablo, "epicúreo”, va a pasar a constituirse en una de las invectivas más frecuentes en el siglo contra toda forma de descreimiento. Servirá para fulminar sus variedades más ajenas: el legendario

\footnotetext{
${ }^{53}$ CSL, 114-120

541 Corintios, 10. 23: «Todo me es lícito, pero no todo me conviene; todo me es lícito, pero no todo edifica».

${ }^{55}$ CSL, 121-122.

56 Como claros son los riesgos de esa especie de "marranismo cristiano" que él denuncia en esos libertinos que "fingen adherirse a todas las supersticiones papistas, ya que, conforme a sus sentencia, todas las cosas externas están en la libertad del cristiano». CSL, 71.

${ }^{57}$ Cfr. Ea los Rom. 8, 1-2: «Ahora, pues, ninguna condenación hay para los que están en Cristo Jesús, los cuales no andan conforme a la carne, sino conforme al espíritu. Porque la ley del espíritu de vida de Cristo Jesús me ha liberado de la ley del pecado y de la muerte».

${ }^{58}$ Epistre contre un cordelier, en CSL, 191-192.
} 
saduceísmo de los heterodoxos sinagogales, como las variedades juzgadas más extremas del libertinismo con raíz en Montaigne primero, del cartesianismo después, finalmente de Spinoza. Epicúreos, ateos, libertinos... Como un infamante escudo de armas, bajo cuyo lema se amalgama toda cuanta novedad la era moderna ve emerger con miedo.

\footnotetext{
'Este texto es un fragmento del Capítulo 2 de un libro sobre el debate libertino en el siglo XVII, aún en curso.
} 